\title{
XI. Account of a cavern discovered on the north- west side of the Mendip hills, in Somersetshire
}

\section{George Smith Gibbes M.B. F.L.S.}

To cite this article: George Smith Gibbes M.B. F.L.S. (1800) XI. Account of a cavern discovered on the north-west side of the Mendip hills, in Somersetshire, Philosophical Magazine Series 1, 7:26, 146-148, DOI: $10.1080 / 14786440008562566$

To link to this article: http://dx.doi.org/10.1080/14786440008562566

曲 Published online: 18 May 2009.

Submit your article to this journal \lceil

Џ Article views: 3

Q View related articles $\sqsubset$ 
are in each fide of each jaw five or fix in number. In the lower jaw each grinder has two tharp points; in the upper jaw each, except the firt pair, has three points.

The neck is very thort, and fo covered with hair as to be fcarcely obfervable. The thoulders are high and round, with a deep cavity between them. The body at the fhoulders is much wider than at the haunches. The buttocks are bare.

The tail is naked, round, and blunt: it is turned up at the end. A ftrong hooked claw in place of the thumb. No carpus nior metacarpus. Four long: fingers ferve to diftend the membrane of the wing. The hind-feet have five diftinet tocs, with fmall tharp claws. The membrane of the wings joins the hinder legs and tall, bat it is not nearly fo long as the latter. A broad hairy lift furrounds all round the body, and covers the bottom of the membrane.

The drawing and defcription were taken from a male. could obferve no nipples.

The natives of Bengal have only two names for all the Species of bats found in their country. The large bats, which neftle on trees, and live chiefly on fruit, they call Badur: thofe which, like the one above defcribed, inhabit caverns and old buildings, and live chiefly on infects, they eall Cbamcbeeka.

Plate IV. reprefents the Vejpertilio plicatus of nearly onehalf its natural fize.

XI. Account of a Cavern difcovered on the-Nortb-Weft Side of the Mendip Hills, in Somerfetfbire. By Geonge Simta Gibies, M. B. F.L.S. ${ }^{*}$

$\mathrm{P}$ ERHAPS the following account of a cavern which I tifited fome time fince may be acceptable, as we there fee the procels going on, which Nature employs to enclofe foreign fubftances in the harder rocks.

At the botton of a deep ravine on the north-weft fide of the Meridip hills, in Somerfethire, near the little village of Berrington, there has been difcovered a cavern of confiderable

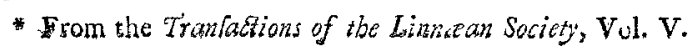


extent, in which was found a great collection of human bones.

As I have obferved in this cavern many circumftances which appear curious to me, I beg leave to mention them, as I do not believe there is another place in the kingdom where the different ftages (if I may be allowed the expreftion) of bones incorporating with limeftone rocks can be fo well. feen. From the top and fides there is a continual dripping of water, which being loaded with a large quantity of calcareous earth, depofits a white kind of pafte on moft parts of the cavern. Many of the bones are incrufted with this cement, and a large proportion of them are actually fxed in the folid rock. I fuppore, therefore, that this fubftance, which at firt is in a ftate refembling mortar, by lofing its water, hardens into a firm and folid ftone. I had an opportunity of examining the procefs in every part, Had the. cavern- not been difcovered, and thefe depofited fubttances, not been removed, I do not doubt that the whole excavation would, in no great length of time, have been completely filled up. The water was fill bringing frefh quantities of calcareous earth, and the bones were in fome places completely incorporated with the folid rock. Every degree of intermediate folidity was plainly difcernible. There were feveral nodules of ftone, each of which contained a perfect human full. The fubftance which is depofited from the water effervefces with acids, and has; in hort, every character of limeftone. At the further end of this very curious cavern, where the height is about fifteen feet, there depends a moft beautiful ftalactite, perfectly conical, which, when the cavern was firft difcoyered, reached within an inch of a cone of the fame kind which rifes from the floor. By fome accident a fmall part of the ftalactite was broken off; but Nature is now bufy in repairing an injury which had been done to one of the prettieft productions of her mineral kingdom. Had thefe two cones met, a beautiful column would have been formed of nearly fifteen feet in height. On ftriking this ftalactite, a found is produced fimilar to that of a bell, which may be heard at a confilerable diftance be yond the mouth of the cavern. 
I examined the bones with confiderable attention, and 1 found that there was adhering to the furface of many of them, a fubftance which refembled the fpermaceti I have before defcribed in the Philofophical Tranfactions for the years 1794 and $I 795$.

I have to add, that this cavern was difeovered about two years ago by accident, and that no fatisfactory reafon has been given for this fingular accumulation of human bones.

XI. Defcription of a Mercurial Air-bolder, fuggefled by an Infpection of Mr. Watt's Macbine for containing Fadtitious. Airs. By William Clayfield*.

$\mathbf{S}_{\mathrm{E}}$ DEVERAL modes of counteracting the preffure of a decreafing column of mercury having been thought of, in conjunction with Mr. W. Cox, the following was at laft adopted as the moft fimple and effectual:

Plate V. Fig. 1 . reprefents a fection of the machine, which confifts of a ftrong glafs cylinder A, cemented to one of the fame kind $B$, fitted to the folid block $C$, into which the glafs tube $\mathrm{D}$ is cemented for conveying air into the moveable receiver $\mathrm{E}$.

The brafs axis $\mathrm{F}$, fig. 2, having a double bearing at $a$, is terminated at one end by the wheel $G$, the circumference of which is equal to the elepth of the receiver, fo that it may be drawn to the furface of the mercury, by the cord $b$, in one revolution; to the other end is fitted the wheel $H$, over which the balance-cord $c$, runs in an oppofite direction in the fpiral groove $e$ : a front view of the wheel $\mathrm{H}$ is fhown at Fig. 3 .

Having loaded the receiver with the weight I, fomething heavier than may be neceffary to force it through the mer-

* From an ingenious work lately pubiined entitled, Rcfearcbess Cbc* mical and Pbiloropbical, cbiefly concerning nitrous Oxyd or depologiflicated nitrous Air, and its Refpiration; by Humpbrey Davy, Superintendent of the Medical Pnewmatic Inftiftation. - This apparatus was fint deforibed in the Third Part of Dr. Beddoes's Confiderations, but it has fince received fome improvements. 